UDC 539.3

\title{
TRANSITIONAL REGIMES UNDER ROUTE TO CHAOS IN VIBROIMPACT SYSTEM
}

\author{
V.A. Bazhenov \\ O.S. Pogorelova \\ T.G. Postnikova ${ }^{1}$ \\ Kyiv National University of Construction and Architecture, \\ 31, Povitroflotskiy avenu, Kyiv, Ukraine
}

In recent years in nonlinear dynamics particular attention was paid to studying the chaotic behaviour of dynamical systems and their routes to chaos. Sometimes this route may be intricate. We watched such intricate route to chaos when studying the quasi-periodic route to chaos in strongly nonlinear non-smooth discontinuous vibroimpact system that was two-body 2-DOF one. After Neimark-Sacker bifurcation many different regimes replace each other. There are transitional regimes with inconsistent characteristics among them. We analyze these regimes with continuous wavelet transform CWT applying. CWT plots confirm just their transition kind and give clear picture of different frequencies presence in time series and their distribution in time.

Keywords: vibroimpact system, route to chaos, transitional regime, Poincaré map, Fourier spectrum, continuous wavelet transform.

\section{Introduction}

At present chaotic dynamics is one of the most interesting and investigated subjects in nonlinear dynamics. Now it is well known that just deterministic chaos is not an exceptional mode of dynamical systems behaviour; on the contrary, chaotic behavior occurs in many dynamical systems in mathematics, mechanics, engineering, physics, chemistry, biology and medicine. Therefore, the studying of chaotic dynamics is one of the main ways of modern natural science development. Now the theory of chaotic vibrations is well developed and is continuing to develop further [1-3].

Let us underline that dynamical deterministic chaos occurs in entirely deterministic systems only under the control parameter changing without any random external influence. And this changing may be very small.

The routes to chaos in nonlinear dynamical systems are of the special scientists' interest. It is known three main routes to chaos in dynamical systems $[1,3]$ :

1) period-doubling route to chaos - the most celebrated scenario for chaotic vibrations, it is Feigenbaum scenario;

2) quasiperiodic route to chaos;

3 ) intermittent route to chaos by Pomeau and Manneville.

We have studied the quasi-periodic and intermittent routes to chaos in vibroimpact system in our previous works $[4,5]$ and references therein.

Vibroimpact system is strongly nonlinear non-smooth discontinuous dynamical system. The studying of its dynamical behaviour has certain

${ }^{1}$ Corresponding author. E-mail address: posttan@ukr.net

(C) Bazhenov V.A., Pogorelova O.S., Postnikova T.G. 
difficulties because of its non-smoothness and discontinuity. When we are comparing the quasi-periodic and intermittent routes to chaos in our vibroimpact system we see that the quasi-periodic route is considerably more intricate then intermittent one. Different oscillatory regimes replace each other many times under very small control parameter varying. There are periodic subharmonic regimes - chatters, quasiperiodic, and chaotic regimes. There are the transitional regimes which occur between other defined ones. What are the transitional regimes? They occur in the zones of transition from one regime to another, they correspond to prechaotic or postchaotic motion. They have the inconsistent characteristics: their Fourier spectrum fits to the one regime kind, Poincaré maps - to another. So we cannot say something specified about its kind.

Therefore we decided to test new technique in order to characterize this multiscale behaviour. This new technique is Continuous wavelet transform CWT.

Wavelet analysis is useful for recognizing periodic and chaotic motions both in the frequency and time domain. It turned out to be an efficient tool for the studying of vibroimpact system dynamic behaviour. In particular it permits the detection of unconformities and other abrupt changes in signal.

In recent years, the wavelet analysis has been applied in many scientific fields. Much commercial software can present the function of wavelet analysis, such as Mathcad and Matlab.

The CWT applying for studying our vibroimpact system dynamic behaviour was very successful one. It was very useful for distinguishing periodic and chaotic regimes. We have "caught" the intermittency due to its helping [5]. It is worth to point out that the intermittency finding is not such an easy task. It is difficulty to discover it by usual ways such as phase trajectories, Poincaré maps, and Fourier spectra construction, even the Lyapunov exponent estimation. Let us remind that under intermittency the laminar phases (periodic regimes) alternate with turbulent ones (chaotic bursts) when the control parameter having the same value. Just because its Fourier spectrum is board and continuous and all other characteristics are such as ones under the chaotic motion. But CWT gives the information about time dependence of the different frequencies. So CWT copes with intermittency recognizing well. It is the reason for analysis of transitional regimes with CWT helping.

\section{Where the transitional regimes were discovered}

We consider the strongly nonlinear non-smooth discontinuous dynamical system which is two body 2-DOF vibroimpact system (Fig. 1) under periodic external loading $F(t)=P \cos \left(\omega t+\varphi_{0}\right)$. Its dynamical behaviour was studied in details in our previous works $[4,5]$ and references therein. Its amplitudefrequency responses in wide frequency range are depicted at Fig. 1 too.

We have watched the quasi-periodic route to chaos, the transient chaos, and hysteresis effects (jump phenomena) in very narrow frequency range $7.45 \mathrm{rad} \cdot \mathrm{s}^{-1}$ $<\omega<8.0 \mathrm{rad} \cdot \mathrm{s}^{-1}$. It is the region between points $K$ and $L$ on amplitude-frequency response where Neimark-Sacker bifurcations occur. At Fig. 2 we show the largest Lyapunov exponent dependence on control parameter that is the frequency of external loading. 

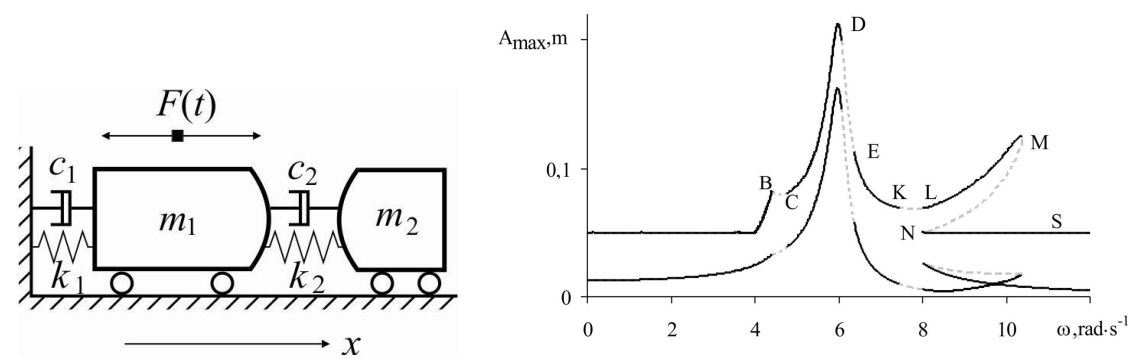

Fig.1. Vibroimpact system model and amplitude-frequency responses

It is worth to remind that the sign of largest Lyapunov exponent $\lambda$ determines sufficiently well the kind of oscillatory motion: the negative sign $\lambda<0$ corresponds to periodic regimes, the positive sign $\lambda>0-$ to chaotic ones, and $\lambda \approx 0$ - to quasi-periodic oscillatory regimes. We see sufficiently intricate route to chaos at this plot. Different oscillatory regimes succeed each other many times under very small control parameter varying in narrow frequency range. There are periodic subharmonic regimes with long period and big number of impact per cycle - chatters, quasiperiodic, and chaotic regimes. The hysteresis effects (jump phenomena) are observed at two frequency ranges.

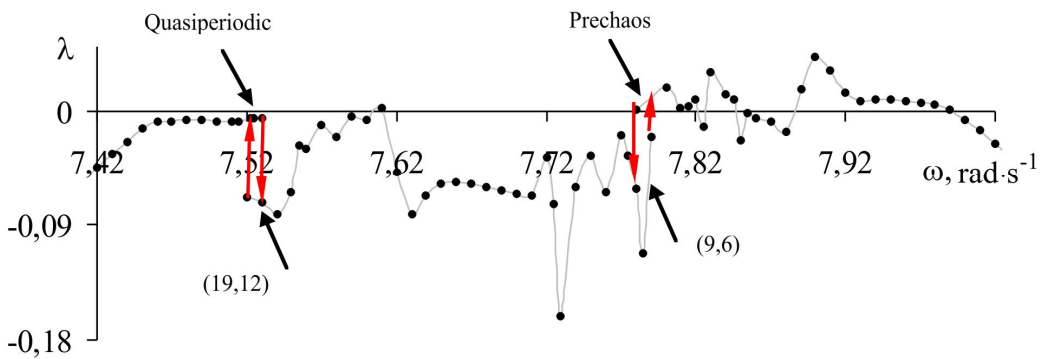

Fig. 2. The largest Lyapunov exponent dependence on control parameter

We see two regions of transitional regimes which occur between other ones. All of them have the small largest Lyapunov exponents, which are near the zero. These regimes are similar to one another. All of them have the conflicting characteristics.

\section{Analysis of transitional regimes}

Let us have a more attentive look at the transitional regimes. Let us attempt to use continuous wavelet transform CWT for more precise its determination. We use software Matlab with Morlet wavelet.

In [5] we showed the view of surfaces of wavelet coefficients (3D plots) and their projections for periodic and chaotic motion. They had different wellpronounced views.

Now let us first have a look at the view of quasi-periodic motion at the wavelet plots. At Fig. 3 we show the characteristics of quasi-periodic regime for attached body $m_{2}$ under $\omega=7.51 \mathrm{rad} \cdot \mathrm{s}^{-1}$. 

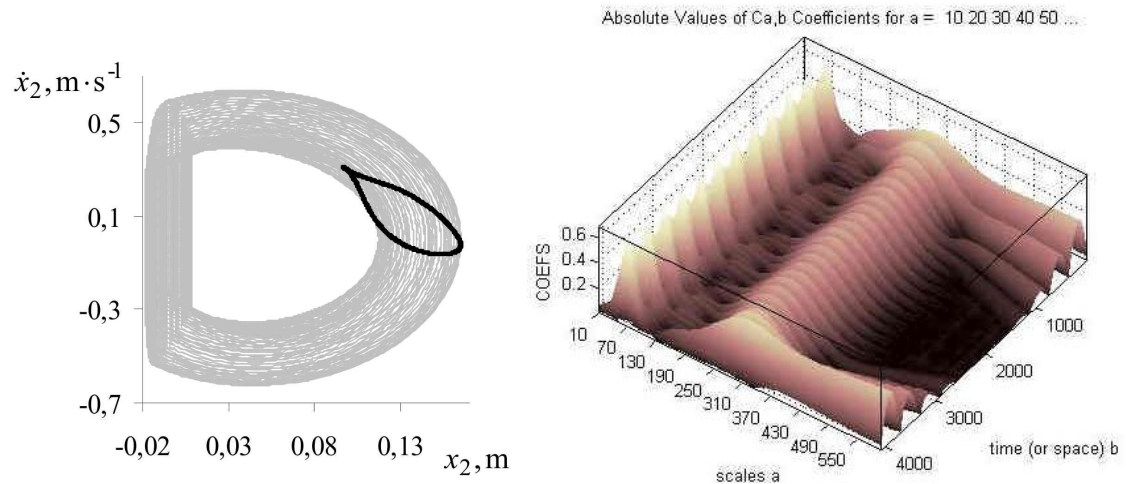

Absolute Values of $C a, b$ Coefficients for $a=111213141$

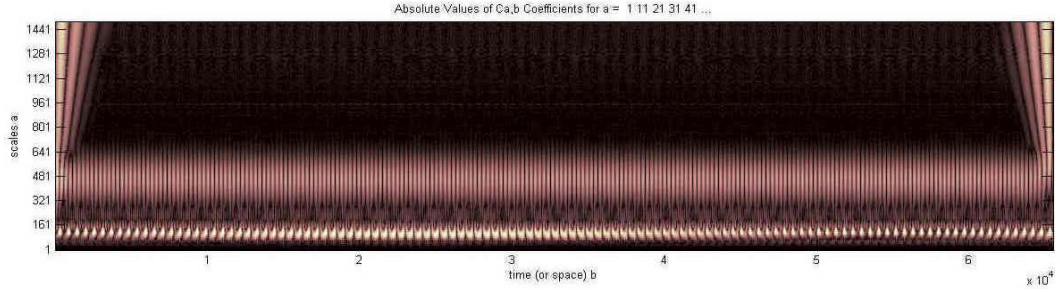

Fig. 3. Phase trajectories, Poincaré maps, wavelet surface projection, and surface of wavelet coefficients for quasi-periodic regime under $\omega=7.51 \mathrm{rad} \cdot \mathrm{s}^{-1}$ (Colour online)

The wavelet plots have not well-pronounced view, they are similar the plots for periodic motions with long periods and big number of impacts per cycle. It is logical as the quasi-periodic motion is almost periodic one.

Now let us have a look at the characteristics of the transitional regime under $\omega=7.61 \mathrm{rad} \cdot \mathrm{s}^{-1}$. We show its phase trajectories with Poincaré map and Fourier spectrum in logarithmic scale at Fig. 4 (for main body $m_{1}$ ). Its Poincaré map is almost closed curve as under quasi-periodic regime, but Fourier spectrum is board and continuous, such as under chaotic motion. These characteristics are inconsistent ones. This regime isn't quasi-periodic, isn't chaotic one. Maybe its wavelet characteristics can show its kind more precisely? At Fig. 4 the wavelet surface projection and surface of wavelet coefficients for this regime are depicted. We see two high frequencies with strong power and a lot of low frequencies with very weak power which provide the continuous Fourier spectrum. They change little in time that provides almost closed curve on Poincaré map. These plots don't make idea about this regime more precise one. But they confirm that this regime does not belong to the kind of quasi-periodic or chaotic one. It is exactly transitional regime.

Let us have more attentive look at the second region of transitional motions under $7.815 \mathrm{rad} \cdot \mathrm{s}^{-1}<\omega<7.90 \mathrm{rad} \cdot \mathrm{s}^{-1}$. We see the chaotic regimes under $\omega=7.80$, $7.81,7.815 \mathrm{rad} \cdot \mathrm{s}^{-1}$. The characteristics for such regime under $\omega=7.815 \mathrm{rad} \cdot \mathrm{s}^{-1}$ are depicted at Fig. 5. 

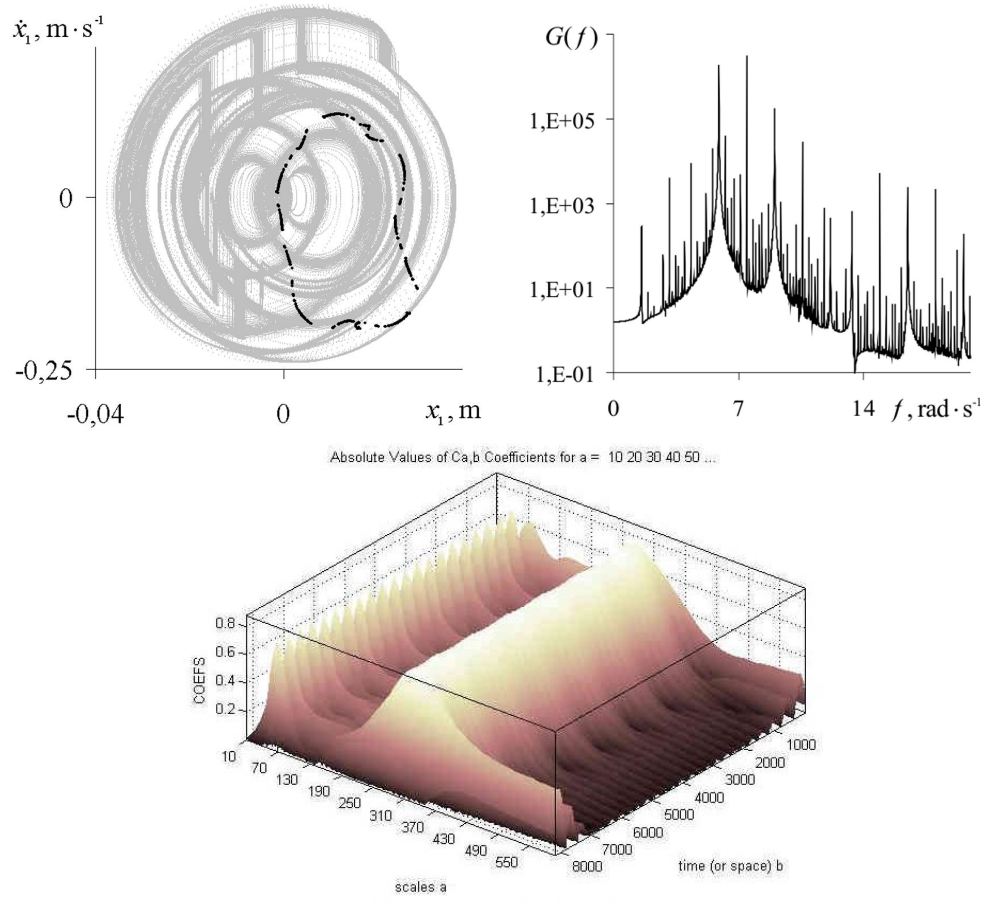

Absolute Vaues of $C a, b$ Coefficients fur $a=111213141$

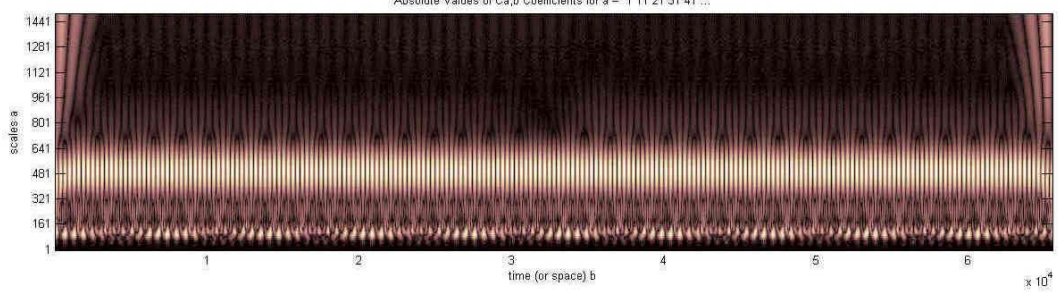

Fig. 4. Phase trajectories, Poincaré map, Fourier spectrum, wavelet surface projection, and surface of wavelet coefficients for transitional regime, $\omega=7.61 \mathrm{rad} \cdot \mathrm{s}^{-1}, \lambda=0.0027$ (Colour online)

These plots have the view which is typical for chaotic motion. Poincaré map is disordered set of points in limited space. The plots of wavelet characteristics display two high frequencies with strong power and a lot of low frequencies with weak power that provide a board continuous Fourier spectrum. It is seen well that all of them are changing in time.

Then we see transitional (prechaotic) regime under $\omega=7.82,7.825 \mathrm{rad} \cdot \mathrm{s}^{-1}$. Its Poincaré map has the set of separate points, but its Fourier spectrum is board and continuous one. Its characteristics under $\omega=7.82 \mathrm{rad} \cdot \mathrm{s}^{-1}$ are depicted at Fig. 6 .

And immediately after this we see the chaotic motion under $\omega=7.83 \mathrm{rad} \cdot \mathrm{s}^{-1}$ (Fig. 7).

We succeeded in finding chaotic regime only under $\omega=7.83 \mathrm{rad} \cdot \mathrm{s}^{-1}$. Immediately after it the transitional regimes with sets of separate points at Poincaré maps and with board continuous Fourier spectra exist under $\omega=7.84$, 
$7.845,7.85 \mathrm{rad} \cdot \mathrm{s}^{-1}$, and further till $\omega=7.90 \mathrm{rad} \cdot \mathrm{s}^{-1}$. They are prechaotic or postchaotic regimes. The characteristics of such regime under $\omega=7.845 \mathrm{rad} \cdot \mathrm{s}^{-1}$ are depicted at Fig. 8.
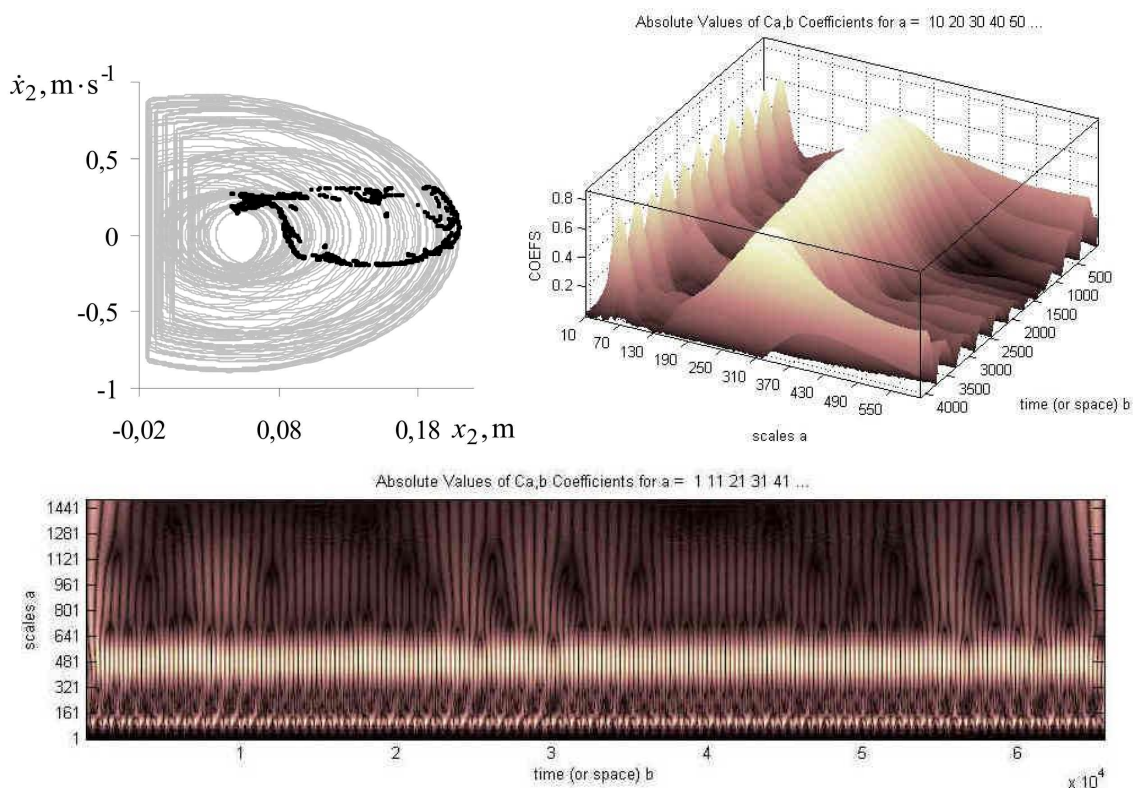

Fig. 5. Phase trajectories, Poincaré maps, wavelet surface projection, and surface of wavelet coefficients for chaotic regime under $\omega=7.815 \mathrm{rad} \cdot \mathrm{s}^{-1}$ (Colour online)
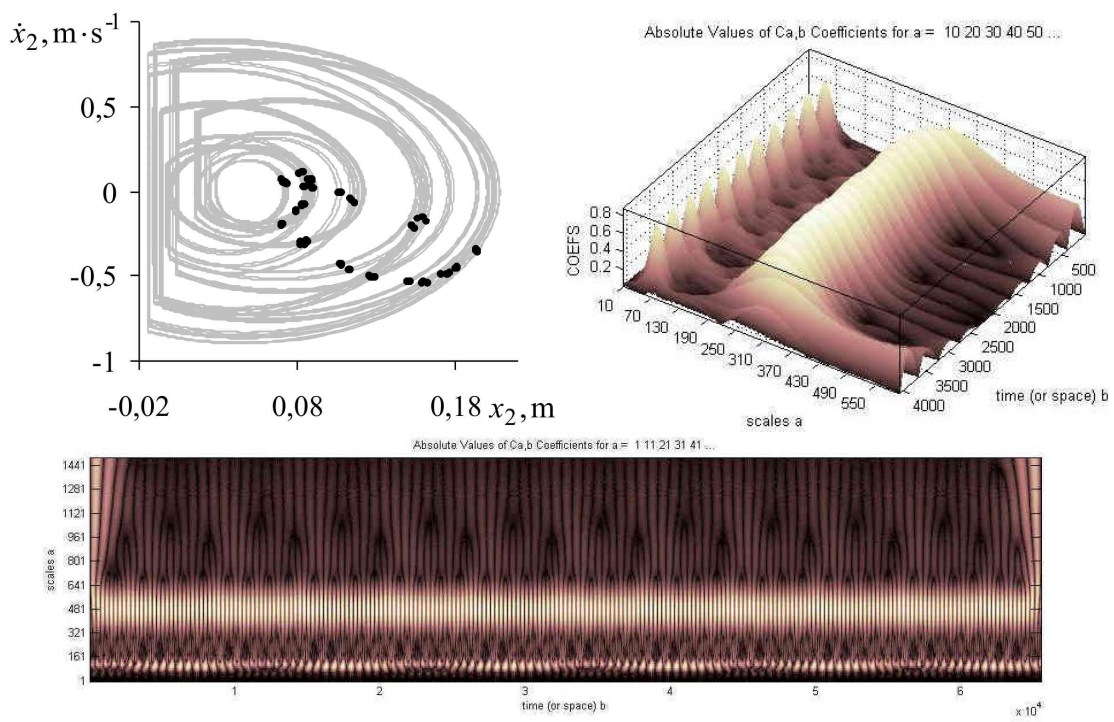

Fig. 6. Phase trajectories, Poincaré maps, wavelet surface projection, and surface of wavelet coefficients for transitional (prechaotic) regime under $\omega=7.82 \mathrm{rad} \cdot \mathrm{s}^{-1}$ (Colour online) 

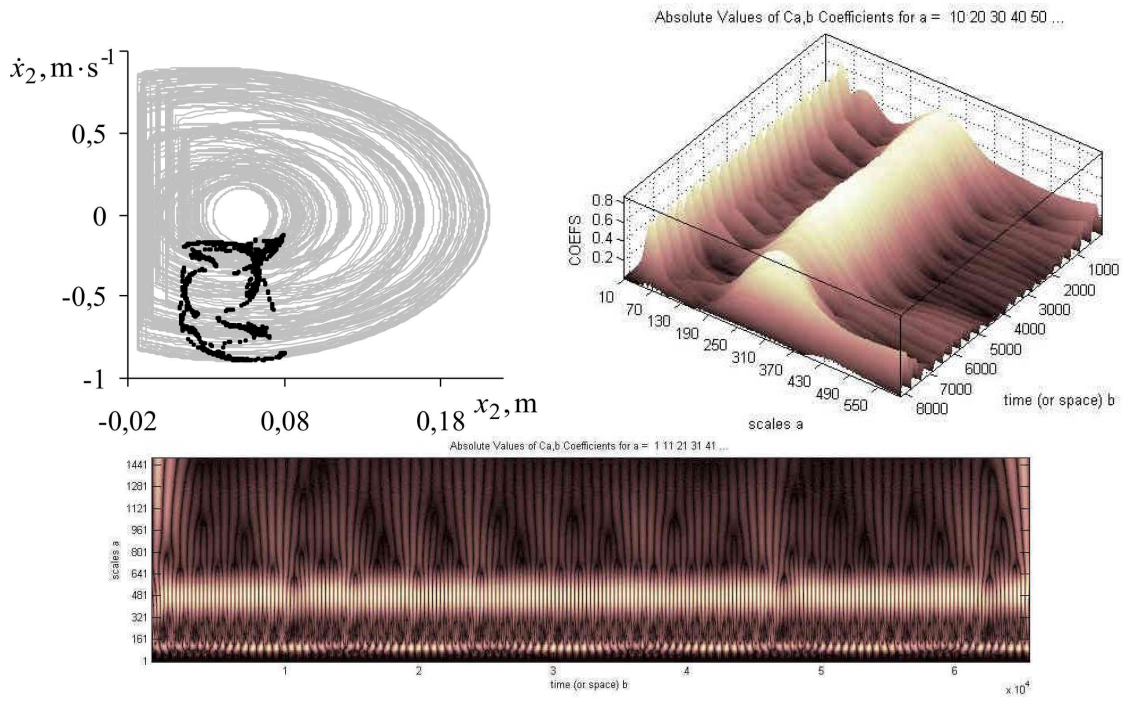

Fig. 7. Phase trajectories, Poincaré maps, wavelet surface projection, and surface of wavelet coefficients for chaotic regime under $\omega=7.83 \mathrm{rad} \cdot \mathrm{s}^{-1}$ (Colour online)
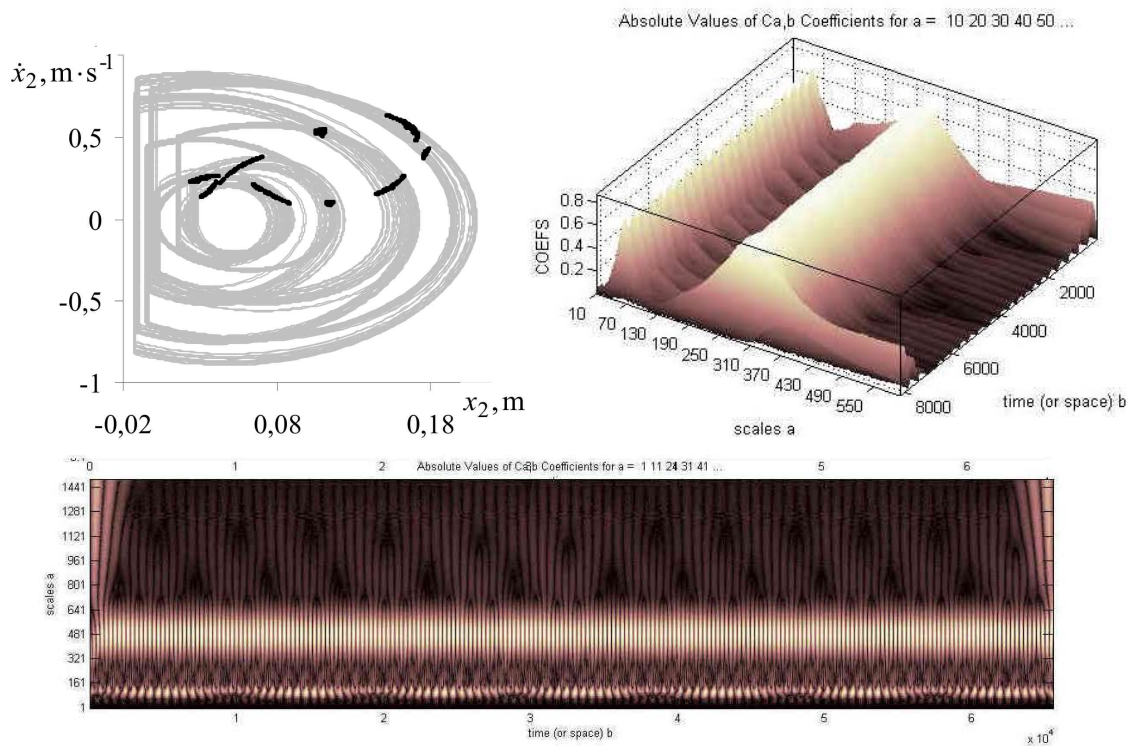

Fig. 8. Phase trajectories, Poincaré maps, wavelet surface projection, and surface of wavelet coefficients for transitional regime under $\omega=7.845 \mathrm{rad} \cdot \mathrm{s}^{-1}$ (Colour online)

Further in narrow frequency range $7.90 \mathrm{rad} \cdot \mathrm{s}^{-1} \leq \omega \leq 7.92 \mathrm{rad} \cdot \mathrm{s}^{-1}$ the really chaotic motion occurs. It is transient chaos. We have examined it in details in [4], therefore now we'll not discuss it. 
We see that all these transitional regimes are similar to one another, they have: the small largest Lyapunov exponent, the set of separate points or almost closed curve on Poincaré map, and the board continuous Fourier spectrum. The characteristics obtained by continuous wavelet transform using also are alike very much.

We see two high frequencies with strong power and a lot of low frequencies with very weak power which provide the continuous Fourier spectrum. They change little in time that provides almost closed curve or a lot of separate points on Poincaré map.

\section{Conclusion}

Continuous wavelet transform CWT is very useful for intermittency recognition and distinguishing the periodic and chaotic regimes. It is indispensable when recognizing the intermittency. So it is logical to apply it when studying the transitional modes.

Transitional regimes are similar to one another, they have: the small largest Lyapunov exponent, the set of separate points or almost closed curve on Poincaré map, and the board continuous Fourier spectrum. The characteristics obtained by continuous wavelet transform applying also are alike very much. The CWT plots confirm that these regimes don't belong to the kind of quasiperiodic or chaotic one. They are exactly transitional regimes. The CWT plots demonstrate the presence of different frequencies in time series and their distribution in time very clearly. Thus continuous wavelet transform is very useful in order to understand well what is this or that transitional mode.

\section{REFERENCES}

1. Moon F.C. Chaotic vibrations: an introduction for applied scientists and engineers. - New York : Wiley, 1987. - 219 P.

2. Kuznetsov S.P. Dynamical chaos //Moscow: Fizmatlit.-2006.-356 P. - 2001.

3. Schuster H.G. Deterministic Chaos. An Introduction 2nd Revised Edition. - 1988.

4. Bazhenov V.A., Pogorelova O.S. \& Postnikova T.G. Invarient Torus break-down in vibroimpact system - route to crisis?.//Strength of Materials and Theory of Structures. - 2018. - V. 100. - P. 3-17.

5. Bazhenov V.A., Pogorelova O.S., Postnikova T.G. \& Lukianchenko O.O. Wavelet transform using for analysis of vibroimpact system chaotic behavior. //Strength of Materials and Theory of Structures. -2018 . - V.101. - P. 14-25.

Стаття надійшла до редакииї 18.03.2019 p.

\section{Баженов В.А., Погорелова О.С., Постнікова Т.Г.}

\section{ПРОМІЖНІ РЕЖИМИ ПІД ЧАС ПЕРЕХОДУ ВІБРОУДАРНОЇ СИСТЕМИ ДО ХАОСУ}

В останні роки в нелінійній динаміці особлива увага приділялася вивченню хаотичної поведінки динамічних систем та сценаріїв їхнього переходу до хаосу. Інколи такий перехід буває складним. Ми спостерігали такий складний перехід до хаосу під час досліджування квазіперіодичного сценарію переходу в сильно нелінійній негладкій розривній двох масовій віброударній системі 3 двома ступнями вільності. Після біфуркації Неймарка-Сакера багато різних режимів заміняли один одного. Серед них були проміжні (перехідні) режими 3 суперечливими характеристиками. Ми аналізуємо ці режими застосовуючи безперервне вейвлет перетворення CWT. Його зображення підтверджують саме їхній перехідний тип та дають наочну картину наявності у часовому ряді різних частот та їхнього розподілу в часі.

Ключові слова: віброударна система, сценарий переходу до хаосу, проміжний режим, відображення Пуанкаре, спектр Фур`є, безперервне вейвлет перетворення. 
UDC 539.3

Bazhenov V.A., Pogorelova O.S., Postnikova T.G. Transiyional regimes under route to chaos in vibroimpact system// Strength of Materials and Theory of Structures: Scientific-and-technical collected articles - Kyiv: KNUBA, 2019. - Issue. 102. - P. 37-45.

In recent years in nonlinear dynamics particular attention was paid to studying the chaotic behaviour of dynamical systems and their routes to chaos. Sometimes this route may be intricate. We watched such intricate route to chaos when studying the quasi-periodic route to chaos in strongly nonlinear non-smooth discontinuous vibroimpact system that was two-body 2-DOF one. After Neimark-Sacker bifurcation many different regimes replace each other. There are transitional regimes with inconsistent characteristics among them. We analyze these regimes with continuous wavelet transform CWT applying. CWT plots confirm just their transition kind and give clear picture of different frequencies presence in time series and their distribution in time.

Fig. 8. Ref. 5

\section{УДК 539.3}

Баженов В.А., Погорелова О.С., Постнікова Т.Г. Проміжні режими під час переходу віброударної системи до хаосу// Опір матеріалів і теорія споруд: наук.-тех. збірн.- К.: КНУБА, 2019. - Вип. 102. - С. 37-45.

В останні роки в нелінійній динаміці особлива увага приділялася вивченню хаотичної поведінки динамічних систем та сиенаріям їхнього переходу до хаосу. Інколи такий перехід буває складним. Ми спостерігали такий складний перехід до хаосу під час досліджування квазіперіодичного сиенарію переходу в сильно нелінійній негладкій розривній двох масовій віброударній системі з двома ступнями вільності. Після біфуркаиії Неймарка-Сакера багато різних режимів заміняли один одного. Серед них були проміжні (перехідні) режими 3 суперечливими характеристиками. Ми аналізусмо иі режими застосовуючи безперервне вейвлет перетворення СWT. Його зображення підтверджують саме їхній перехідний тип та дають наочну картину наявності у часовому ряді різних частот та їхнього розподілу в часі. Іл. 8. Бібліог. 5 назв.

Автор (вчена ступень, вчене звання, посада): доктор технічних наук, професор, академік Національної академії педагогічних наук України, директор НДI будівельної механіки БАЖЕНОВ Віктор Андрійович

Адреса робоча: 03680 Украӥна, м. Київ, Повітрофлотський проспект 31, Київський національний університет будівниџтва і архітектури, БАЖЕНОВУ Віктору Андрійовичу

Робочий тел.: +38(044) 245-48-29;

Мобільний тел.: +38(067) 111-22-33;

E-mail: vikabazh@ukr.net

ORCID ID: http://orcid.org/0000-0002-5802-9848

Автор (вчена ступень, вчене звання, посада): кандидат фізико-математичних наук, старший науковий співробітник, провідний науковий співробітник НДI будівельної механіки ПОГОРЕЛОВА Ольга Семенівна

Адреса робоча: 03680 Украӥна, м. Киӥв, Повітрофлотський проспект 31, Київський національний університет будівництва і архітектури, ПОГОРЕЛОВІЙ Ользі Семенівні.

Робочий тел.: +38(044) 245-48-29

Мобільний тел.: +38(067) 606-03-00

E-mail: pogos13@ukr.net

ORCID ID: http://orcid.org/0000-0002-5522-3995

Автор (вчена ступень, вчене звання, посада): кандидат технічних наук, старший науковий співробітник, старший науковий співробітник НДІ будівельної механіки ПОСТНІКОВА Тетяна Георгї̈на

Адреса робоча: 03680 Украӥна, м. Київ, Повітрофлотський проспект 31, Київський національний університет будівництва і архітектури, ПОСТНІКОВІЙ Тетяні Георгї̈вні.

Робочий тел.: +38(044) 245-48-29

Мобільний тел.: +38(050) 353-47-19

E-mail: posttan@ukr.net

ORCID ID: http://orcid.org/0000-0002-6677-4127 